\title{
CRITICALLY SOVEREIGN
}


This page intentionally left blank 


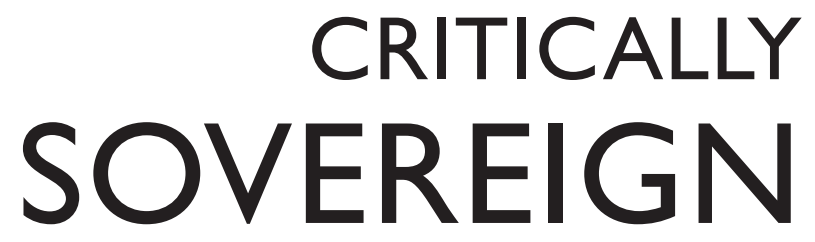

Indigenous Gender, Sexuality, and Feminist Studies

JOANNE BARKER, EDITOR

DUKE UNIVERSITY PRESS

Durham and London · 2017 
(C) 2017 Duke University Press

All rights reserved

Printed in the United States of America on acid-free paper $\infty$

Designed by Courtney Leigh Baker

Typeset in Arno Pro and Trade Gothic by Westchester Publishing Services

Library of Congress Cataloging-in-Publication Data

Names: Barker, Joanne, [date] editor.

Title: Critically sovereign : indigenous gender, sexuality, and feminist studies / Joanne Barker, editor.

Description: Durham : Duke University Press, 2017. | Includes bibliographical references and index.

Identifiers: LCCN 2016048394 (print) | LCCN 2016050624 (ebook)

ISBN 9780822363392 (hardcover : alk. paper)

ISBN 9780822363651 (pbk. : alk. paper)

ISBN 9780822373162 (e-book)

Subjects: LCSH: Indians of North America-Historiography. | Indigenous

peoples_Historiography. | Sex role_Political aspects—United States-History. |

Feminist theory. | Queer theory. | Decolonization-United States. | Indigenous peoples in literature.

Classification: LCC E76.8 .C75 2017 (print) | LCC E76.8 (ebook) | DDC 970.004/97—dc23

LC record available at https://lccn.loc.gov/2016048394

COVER ART: Merritt Johnson, Waterfall Face Emergency Mantle for Diplomatic Security and Near Invisibility, 2014, fabric, turkey wings, beads and spray lacquer. 
TO ALL THE murdered and missing Indigenous women and gender nonconforming individuals.

TO THE

Grandmothers, Aunts, Sisters, Mothers, Daughters, Friends, Lovers.

May all our relatives find peace and justice. 
This page intentionally left blank 